\title{
A model of bank capital, lending and the macroeconomy: Basel I versus Basel II
}

\author{
Lea Zicchino*
}

Working Paper no. 270

* Bank of England, Financial Industry and Regulation Division.

Email: lea.zicchino@bankofengland.co.uk

This paper represents the views and analysis of the author and should not be thought to represent those of the Bank of England. I would like to thank Ralph Chami, Charles Goodhart, Glenn Hoggarth, Erlend Nier, Hyun Song Shin, Dimitrios Tsomocos, Geoffrey Wood, seminar participants at the Bank of England, and an anonymous referee for helpful comments. I am, of course, responsible of any remaining errors. This paper was finalised on 15 June 2005.

Copies of working papers may be obtained from Publications Group, Bank of England, Threadneedle Street, London, EC2R 8AH; telephone 0207601 4030, fax 0207601 3298, e-mail mapublications@bankofengland.co.uk

Working papers are also available at www.bankofengland.co.uk/wp/index.html

The Bank of England's working paper series is externally refereed. 



\section{Contents}

$\begin{array}{ll}\text { Abstract } & 5\end{array}$

$\begin{array}{ll}\text { Summary } & 7\end{array}$

1 Introduction $\quad 9$

2 Chami-Cosimano (2001) 12

$3 \quad$ Extension to the model and results $\quad 17$

4 Concluding remarks $\quad 30$

$\begin{array}{ll}\text { Appendix } & 32\end{array}$

$\begin{array}{ll}\text { References } & 43\end{array}$ 



\begin{abstract}
The revised framework for capital regulation of internationally active banks (known as Basel II) introduces risk-based capital requirements. This paper analyses the relationship between bank capital, lending and macroeconomic activity under the new capital adequacy regime. It extends a model of the bank-capital channel of monetary policy - developed by Chami and Cosimano - by introducing capital constraints à la Basel II. The results suggest that bank capital is likely to be less variable under the new capital adequacy regime than under the current one, which is characterised by invariant asset risk-weights. However, bank lending is likely to be more responsive to macroeconomic shocks.
\end{abstract}

Key words: Capital adequacy, regulation, bank lending, procyclicality.

JEL classification: E5, G2. 



\section{Summary}

The process of reforming the 1988 Basel Accord, that started in 1999, has been motivated by the goal of more closely matching regulatory capital to the risk profile of banks' asset portfolios. The rationale for minimum capital requirements is that they mitigate financial institutions' moral hazard. Regulators are imposing a cost on bank owners to 'encourage' them to avoid costly default. However, the limited number of risk categories in the current framework has created opportunities for banks to increase the risk to which they are exposed without increasing the amount of regulatory capital.

The new Basel Accord is widely recognised as a much needed effort to deal with the shortcomings of the current system. By realigning capital adequacy rules with banks' incentives it aims at restoring the link between risk and capital holding. Nonetheless, a number of questions have been raised by central bankers, regulators and practitioners regarding the impact of a more risk-sensitive regulatory framework on macroeconomic stability. Among them, there is the issue

of the potential procyclical effects of the new capital adequacy requirements, ie the possibility that during periods of weak economic growth, a fall in capital ratios and an increase in regulatory requirements implied by a deterioration in the risk profile of banks' assets might increase the likelihood of credit contraction and, therefore, a further weakening of growth.

This paper analyses the relationship between banks' capital holdings, banks' loans and macroeconomic activity under risk-sensitive capital adequacy requirements. In particular, it compares the impact of macroeconomic shocks on banks' choices of capital structure and loan supply under the old and new capital adequacy regimes. It does so by extending a model that investigates the impact of monetary policy on lending in an economy where banks operate in an oligopolistic market and are subject to minimum capital requirements. In order to analyse banks' reaction to changes in macroeconomic conditions under the new capital adequacy regime, I extend the model by assuming a link between loan risk-weights and borrowers' creditworthiness. In particular, I introduce asset risk-weights that vary with macroeconomic performance, which is a major determinant of credit risk.

The first result of the paper is that the response of banks to shocks that affect loan demand differs when the minimum capital requirements are calculated with asset risk-weights that are sensitive to 
macroeconomic conditions. In particular, bank capital is less volatile than under capital requirements with constant risk-weights. The intuition behind this result can be understood by considering, for example, a positive shock to macroeconomic conditions that increases both current and future loan demand. If the capital constraint is binding, banks may not be able to expand loan supply in the current period and they may need to raise capital to increase supply in the future. Therefore, if capital requirements do not change with borrowers' risk, capital increases in response to positive macroeconomic shocks and decreases after negative shocks. But when asset risk-weights depend on macroeconomic conditions, bank capital might not need to increase for banks to be able to expand their credit supply. In fact, following a positive macroeconomic shock the risk-weights decrease and the capital constraint thus become looser. This insight has an important policy implication. On the one hand banks will tend to operate above the minimum regulatory capital to avoid the capital constraint becoming binding in future periods. On the other hand banks may not voluntarily accumulate capital in times of good macroeconomic conditions because it is during these times that the capital constraint becomes looser. This means that if banks are affected by an adverse shock during a period of credit expansion, they might be forced to raise capital at a time when market conditions are unfavourable. A second and related result of the paper concerns the effect of macroeconomic shocks on loan supply. Since capital is more difficult to accumulate in a recession, and easier to accumulate when the economy experiences a positive shock, bank credit is likely to be more procyclical under the new Accord than under the current one. 


\section{Introduction}

The aim of this paper is to analyse the relationship between macroeconomic conditions, bank capital and lending when banks are subject to risk-sensitive capital adequacy requirements as envisaged in the new Basel proposals. ${ }^{(1)}$

The process of reforming the Basel Accord, begun in 1999, has been motivated by the goal of more closely matching regulatory capital to the risk profile of banks' asset portfolios. The rationale for minimum capital requirements is that they mitigate financial institutions' moral hazard. Regulators are imposing a cost on bank owners to 'encourage' them to avoid costly default. But the limited number of risk categories in the current framework has created opportunities for banks to increase the risk to which they are exposed without increasing the amount of regulatory capital. There are a number of ways in which banks are able to engage in capital arbitrage. For example, banks can sell or securitise those assets for which the regulatory capital charge is believed to be higher than the one markets would impose while keeping on the books poorer quality assets for which the regulatory capital charge is relatively low.

The new Basel Accord is widely recognised as a much needed effort to deal with the shortcomings of the current system. By realigning capital adequacy rules with banks' incentives it aims at restoring the link between risk and capital holding. Nonetheless, a number of questions have been raised by central bankers, regulators and practitioners regarding the impact of a more risk-sensitive regulatory framework on macroeconomic stability. Among them, there is the issue of the potential procyclical effects of the new capital adequacy requirements, ie the possibility that during periods of weak economic growth, the rise in regulatory requirements implied by a deterioration in the risk profile of banks' assets might lead to a reduction of credit supply and thus reinforce the weakening of macroeconomic conditions.

Empirical evidence shows some support for the idea that the credit crunch experienced in the United States during the 1990 recession might have been caused, or at least accentuated, by the introduction of capital requirements. Bernanke and Lown (1991) use US state-level data on individual banks to argue that, although demand factors might have caused much of the observed slowdown in bank lending during the period, a shortage of equity capital limited banks' ability to

(1) See Basel Committee on Banking Supervision (2004) for a description of the Basel II Accord. 
extend loans, particularly in the northeastern part of the country. Lower levels of bank capital seem to have been the result of an increase in loan defaults and write-offs. ${ }^{(2)}$

If the weights used to set capital requirements are sensitive to changes in risk, as proposed under the new Accord, required regulatory capital may increase at the same time that actual levels of bank capital are decreasing. Risk-weights would increase during recessions because of a higher probability of default and potentially also because of a higher loss given default on loans. So in order to maintain a given ratio of capital to risk-weighted assets, banks will need to hold more regulatory capital. This rise in capital requirements would coincide with a period during which banks' profits, and potentially actual capital, may be falling as a consequence of bad loans being charged off. In a recent paper, Catarineu-Rabell, Jackson and Tsomocos (2003) suggest that many banks have moved towards point-in-time rating methods when determining credit risk. Under an internal ratings based (IRB) approach to the implementation of the new capital adequacy regulation, banks would therefore determine the risk-weights based on a Merton-type model where current information on borrowers' equity price and book liabilities is used to obtain estimates of borrowers' probabilities of default. Since cyclical effects in asset valuations would be reflected in the default probabilities, the Merton-model approach delivers risk-weights that are highly sensitive to current economic conditions.

Apart from Catarineu-Rabell et al, there are few papers that analyse the impact of capital regulation on banks' behaviour. However, over the past few years a related literature has emerged which analyses the link between bank capital and lending in models of monetary policy. ${ }^{(3)}$ In addition to the more conventional mechanisms of propagation and amplification of monetary policy shocks, a new type of credit channel (a so-called 'bank capital channel') has been identified. ${ }^{(4)}$ According to the 'bank capital channel' view, a change in interest rates can affect lending through banks' capital. This transmission mechanism is operative when banks' lending is constrained by a capital adequacy requirement. An increase in official interest rates, for example, will raise the cost of banks' external funding, reduce their profits and possibly their capital.

(2) For more evidence on the impact of capital requirements on bank lending see Jackson et al (1999), Hancock, Laing and Wilcox (1995), Haubrich and Wachtel (1993), Thakor (1996) and Wagster (1999).

(3) See, among others, Bliss and Kaufman (2002), Chami and Cosimano (2001), Tsomocos (2003), and Van den Heuvel (2001).

(4) See Van den Heuvel (2002) for a brief description of the various channels of monetary policy transmission. 
If the capital constraint becomes binding, banks will need to decrease their supply of credit. ${ }^{(5)}$

It is important, however, to notice that the bank capital channel may operate in response to factors other than changes in monetary policy. Changes in regulatory policy or simply shocks to macroeconomic conditions may also shift banks' lending by affecting their regulatory capital constraint. This last mechanism will be the focus of the analysis in this paper.

The impact of macroeconomic conditions on bank capital and loans is examined by using the framework developed by Chami and Cosimano (2001). In their paper, Chami and Cosimano (C-C) analyse the effect of monetary policy in an economy characterised by banks operating under capital adequacy constraints in an imperfectly competitive loan market. The model assumes that minimum capital requirements are constant over time à la Basel $\mathrm{I}^{(6)}$ and that bank loans are risk-free. In order to analyse banks' incentives and the impact of macroeconomic conditions on banks' choices under the new Accord, I introduce two key extensions. First, it is assumed that borrowers can default and thus that banks make credit losses. Loan write-offs are modelled as being dependent on macroeconomic conditions, consistent with empirical evidence that banks' losses on loan portfolios are correlated with the business cycle, under any capital adequacy regime. Second, asset risk-weights are assumed to vary over the business cycle. This assumption intends to capture the link between loan risk-weights and borrowers' creditworthiness established in the new Basel rules.

In order to compare the impact of the current and revised capital adequacy standards (ie Basel I and Basel II) on banks' behaviour, I introduce the two extensions sequentially. First, I present the results of the model under the assumption that banks make losses on loans but that risk-weights are constant, as under Basel I. Then, I will show the consequences of asset risk-weights that vary with macroeconomic conditions, as under Basel II.

The rest of the paper is organised as follows: Section 2 provides a brief summary of the C-C

(5) In Chen (2001) a bank's net worth can impact on lending without a capital adequacy constraint. Bank capital has a role in overcoming the moral hazard problem arising from asymmetric information between banks, depositors and borrowers.

(6) The first Capital Accord, published in July 1988 and implemented by the end of 1992, prescribes minimum capital to asset ratios. All assets are assigned to one of four buckets, which classify the riskiness of the respective contract (eg loans to OECD governments, loans to OECD banks and other OECD public sector entities, residential mortgage loans, loans to the private sector). The same constant risk-weight is then associated to the assets in the same risk bucket. 
paper, Section 3 presents the extension to the $\mathrm{C}-\mathrm{C}$ model and the main results, Section 4 concludes and discusses further work.

\section{Chami-Cosimano (2001)}

The C-C paper analyses the bank capital channel of monetary policy by using a dynamic model in which banks maximise the present value of future profits, subject to a minimum capital-asset ratio. In anticipating that the capital constraint may bind in the future, banks choose an optimal level of dividend payouts (or, equivalently, capital) each period to minimise this possibility. Monetary policy affects the supply of loans by affecting the value of holding bank capital. For example, a tightening of monetary policy, which causes an increase in current and future deposit rates, reduces banks' current and future loan supply. A lower loan supply gives banks the incentive to hold less capital. But a lower level of capital will make the constraint on future lending more restrictive. In sum, contractionary monetary policy reduces future credit supply not only because it increases the marginal cost of loans but also because it causes a reduction in banks' capital.

Before briefly presenting the model, I will discuss banks' capital constraint and banks' cash flows as presented by $\mathrm{C}-\mathrm{C}$.

The total capital constraint requires that the sum of Tier 1 and Tier 2 capital $^{(7)}$ be no less than a given ratio of risk-adjusted assets:

$$
\theta L_{t} \leq q_{t-1} s_{t}+b_{t}
$$

where $q_{t-1} s_{t}$ (Tier 1 capital) is the previous period's market value of equity (price $q$ at time $t-1$ times number of shares $s$ ), $L_{t}$ are one-period loans, $b_{t}$ are one-period bonds (subordinated debt in the Basel Accord) issued in the previous period, and $\theta$ is the regulatory ratio of Tier 1 plus Tier 2 capital to risk-adjusted assets. To maintain the book value feature of regulatory capital, it is assumed that last period's market value of equity and bonds determines the capital constraint for the present period.

(7) Tier 1 capital is the book value of a bank's stock plus retained earnings. Tier 2 capital is the sum of loan-loss reserves and subordinated debt. 
The following identity describes the sources and uses of cash flows $n_{t}$ generated by the bank:

$$
n_{t} \equiv \pi_{t}=d_{t} s_{t}+\left(1+r_{t}^{b}\right) b_{t}-q_{t}\left(s_{t+1}-s_{t}\right)-b_{t+1}
$$

where $\pi_{t}$ are profits, $d_{t} s_{t}$ are dividend payments and $r_{t}^{b}$ is the interest rate on one-period bonds. ${ }^{(8)}$

The banking industry is assumed to operate in an oligopolistic market for loans: there are $N$ banks that charge a loan rate consistent with monopoly power. An individual bank precommits to a quantity of loans through its capital holding (since the current choice of capital restricts the supply of loans next period), and loan rate competition follows in the next period.

To characterise the equilibrium, C-C analyse the behaviour of a bank operating as a monopolist. ${ }^{(9)}$ The bank attracts deposits $D_{t}$ at a fixed marginal cost $c_{D}$. The bank holds $\alpha D_{t}$ as reserves against withdrawals of money. Assume these withdrawals $x$ come from a probability distribution $f(x)$. If at any time $x$ exceeds the amount of marketable securities $T_{t}$ (held in addition to reserves), then the bank has to liquidate assets at a penalty rate $r_{t}^{p}$.

The bank faces the following loan demand:

$$
L_{t}=l_{0}-l_{1} r_{t}^{L}+l_{2} M_{t}+\varepsilon_{L, t}
$$

where $r_{t}^{L}$ is the loan rate, $M_{t}$ is a variable representing the level of macroeconomic activity and

(8) Bank profits $\pi_{t}$ are used to meet obligations: dividend payments on equity, and interest and principal payments on bonds, such that retained earning are described by $r e_{t}=\pi_{t}-d_{t} s_{t}-\left(1+r_{t}^{b}\right) b_{t}$. Banks should also invest in plant and equipment each period. For simplicity we can assume that there is no investment in new physical capital and that the depreciation rate of banks' capital stock is $\psi$. Banks finance the depreciation $\psi k_{t}$ through retained earnings, new equity or new bonds: $\psi k_{t}=r e_{t}+q_{t}\left(s_{t+1}-s_{t}\right)$ such that the net cash flow is given by

$$
n_{t} \equiv \pi_{t}-\psi k_{t}=d_{t} s_{t}+\left(1+r_{t}^{b}\right) b_{t}-q_{t}\left(s_{t+1}-s_{t}\right)-b_{t+1} .
$$

Without loss of generality, we can set $\psi k_{t}=0$. Thus, if for example $\left(1+r_{t}^{b}\right) b_{t}=b_{t+1}$, ie the subordinated debt is rolled over each period, then the equation above becomes:

$$
\pi_{t}-d_{t} s_{t}=-q_{t}\left(s_{t+1}-s_{t}\right) \text {. }
$$

If $\pi_{t}>d_{t} s_{t}$, then $q_{t}\left(s_{t+1}-s_{t}\right)<0$. This implies that banks do not keep retained earnings on their balance sheets as cash. If not completely paid out as dividends, and if debt is rolled over, earnings are used to decrease liabilities (unless banks decide to hold more capital to increase loan supply, as we will see later).

(9) See the appendix or Chami-Cosimano (2001) for a discussion of the condition under which the game played by oligopolistic banks has a co-operative solution. 
$\varepsilon_{L, t}$ represents a random exogenous shock to the demand for loans, which is defined over the interval $[\underline{L}, \bar{L}] \cdot{ }^{(10)}$

The bank maximises its value by choosing the loan rate, its level of deposits, its investment in treasury securities, and its capital, subject to the cash-flow constraint (5), the loan demand (6), the financing constraint (7) and the balance-sheet identity (8):

$$
\begin{aligned}
\operatorname{Max} v\left(q_{t-1} s_{t}+b_{t}, x_{t}\right)= & \left\{\pi_{t}+\lambda_{t}\left[q_{t-1} s_{t}+b_{t}-\theta L_{t}\right]-\tau_{t}\left[q_{t} s_{t+1}+b_{t+1}\right]+\right. \\
& \left.E_{t}\left[m_{t, 1} v\left(q_{t} s_{t+1}+b_{t+1}, x_{t+1}\right)\right]\right\}
\end{aligned}
$$

subject to:

$$
\begin{gathered}
\pi_{t}=r_{t}^{L} L_{t}+r_{t}^{T} T_{t}-r_{t}^{D} D_{t}-c_{L} L_{t}-c_{D} D_{t}-\frac{r_{t}^{p}}{2 \bar{D}}\left(\bar{D}-T_{t}\right)^{2} \\
L_{t}=l_{0}-l_{1} r_{t}^{L}+l_{2} M_{t}+\varepsilon_{L, t} \\
q_{t} s_{t+1}+b_{t+1}=\left(d_{t}+q_{t}\right) s_{t}+\left(1+r_{t}^{b}\right) b_{t}-\pi_{t} \\
T_{t}=(1-\alpha) D_{t}-L_{t}+q_{t-1} s_{t}+b_{t}
\end{gathered}
$$

(10) As observed by an anonymous referee, some models propose that firms' demand for external funds (and thus for bank loans) may increase following a fall in firms' internal funds, ie when macroeconomic conditions deteriorate. Here, I follow C-C in assuming a Hicksian loan demand that is an increasing function of GDP and a decreasing function of the interest rate. 
In the value function, $\lambda_{t}$ is the Lagrange multiplier for the capital constraint, $\tau_{t}$ is the deadweight cost of capital ${ }^{(11)}$ and $m_{t, 1}$ is a stochastic discount factor. In the profit function, $c_{L}$ is the constant marginal cost of loans (representing the cost of monitoring and screening), $c_{D}$ is a constant component of the cost of deposits (representing the cost of cheque clearing and bookkeeping), and $\frac{r_{t}^{p}}{2 D}\left(\bar{D}-T_{t}\right)^{2}$ is the cost of deposit withdrawals. ${ }^{(12)}$

The level of macroeconomic activity $M$, and the interest rate on deposits $r^{D}$ are assumed to follow a first-order autoregressive stochastic process: ${ }^{(13)}$

$$
M_{t+1}=\rho_{M} M_{t}+\varepsilon_{M, t+1}
$$

and

$$
r_{t+1}^{D}=\rho_{r^{D}} r_{t}^{D}+\varepsilon_{r^{D}, t+1}
$$

where $\varepsilon_{M, t+1}$, and $\varepsilon_{r^{D}, t+1}$ are zero-mean stochastic shocks to economic activity and deposit rate, respectively. One may think of $\varepsilon_{M, t+1}$ as a temporary shock to GDP, either a demand shock, for example a temporary shift in government purchases or in consumer confidence, or a supply shock, for example an oil price shock.

When solving this problem, last period's choice of capital is taken as given and determines whether or not the capital constraint is binding this period. Further, it turns out that the solution of the problem separates the bank's desired capital from its other choices. Therefore, decisions on loan interest rate, deposits and marketable securities can be analysed as in a static problem. When the capital constraint is non-binding, the optimal level of loans occurs where the marginal revenue

(11) In the model there is no difference between the relative cost of raising subordinated debt versus equity.

(12) The cost of deposit withdrawals is obtained as follows:

$$
C\left(T_{t}\right)=r_{t}^{p} \int_{T}^{\infty}\left(x-T_{t}\right) f(x) d x=\frac{r_{t}^{p}}{2 \bar{D}}\left(\bar{D}-T_{t}\right)^{2}
$$

where $x$ is assumed to have a uniform distribution with support $[\underline{D}, \bar{D}]$.

(13) The fact that shocks to macroeconomic conditions $M$ and to deposit rate $r^{D}$ (which approximate monetary policy) are not correlated means that the model does not have a well-defined monetary policy rule. Otherwise, we would expect shocks in $M$ to affect $r^{D}$. I owe this point to an anonymous referee. 
from loans is equal to the marginal cost of loans (point A in Figure 1 below). If there is an increase in loan demand (an upward shift of the demand curve), both the quantity and the price of loans (the interest rate $r_{L}$ ) increase. If the marginal cost of loans decreases, the quantity of loans will increase, while the interest rate will decrease.

\section{Figure 1: Loan market equilibrium in the $\mathrm{C}-\mathrm{C}$ model}

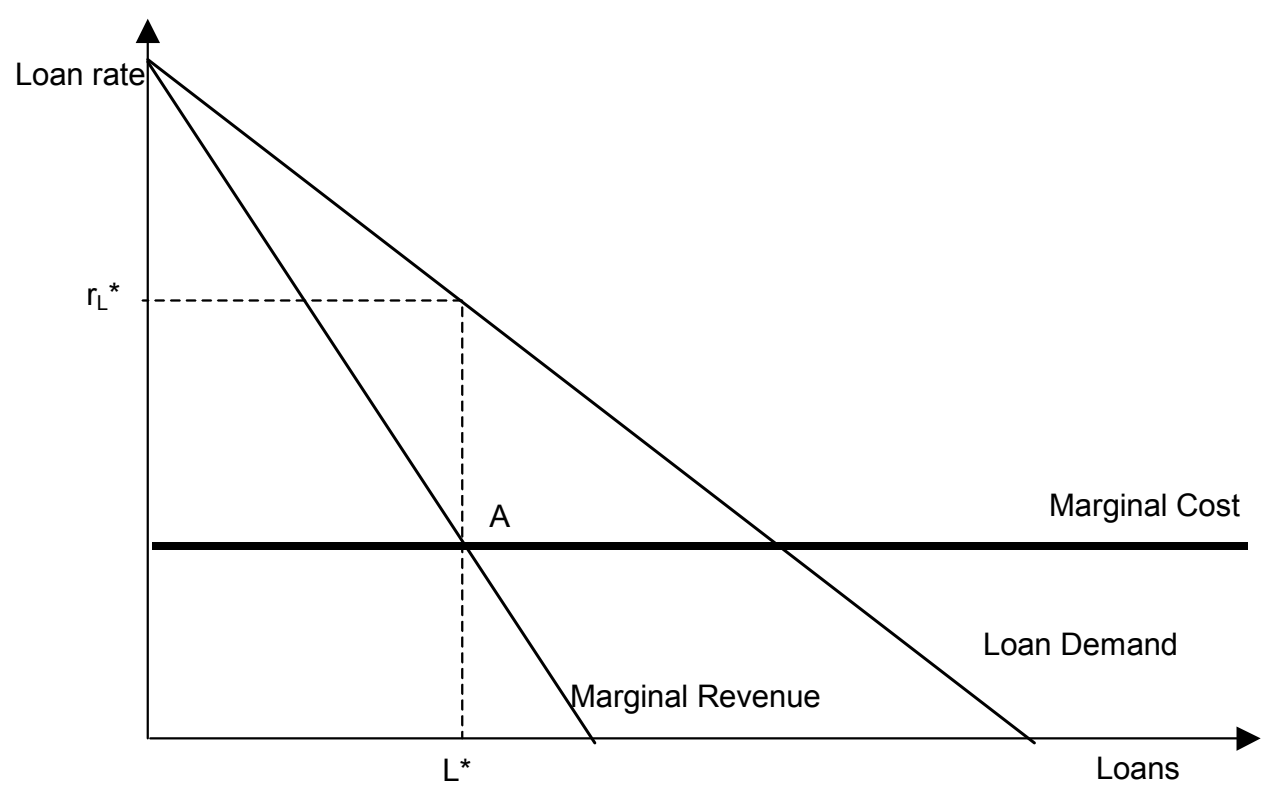

However, if the capital constraint is binding and loans are at their ceiling $L^{*}$, then an increase in the loan demand or a decrease in the marginal cost of loans do not affect the supply of credit but only the loan rate, $r^{L}$.

In deciding the amount of capital to hold, the bank compares the marginal deadweight cost of capital, $\tau$, with the expected marginal benefit. The latter has two components. First, additional equity (or subordinated debt) reduces the need for raising deposits in the next period. Second, there is the expected marginal benefit from the fact that the capital constraint is less likely to be binding in the next period, $\lambda_{t+1}^{*} \cdot{ }^{(14)}$

The resulting optimal capital held by banks depends on a number of factors: (1) it is a negative

(14) The optimal bank capital is the solution to the first-order condition that equates $\tau$, the cost of capital, to the expected marginal cost of deposits, which is the alternative source of financing for the bank, plus $\lambda_{t+1}^{*}$, which is the shadow value of the capital constraint (ie it represents the marginal increase in the optimal value of the objective function of the bank if the capital constraint is relaxed). 
function of the expected marginal cost of external funds (which is equal to the difference between the marginal deadweight cost of capital $\tau$ and the expected marginal benefit of capital, as just described); (2) a positive function of the expected demand for loans (which is, in turn, a function of current economic conditions, due to the autoregressive nature of the stochastic process

characterising $M)$; (3) a negative function of the expected marginal cost of loans $\left(\frac{r_{t}^{D}+c_{D}}{1-\alpha}+c_{L}\right)$, and within that of the deposit rate $r_{t}^{D}$; (4) a positive function of the volatility of loan demand; (5) a negative function of the elasticity of the loan demand (bigger elasticity implies less monopoly power); and (6) a positive function - under a parametric assumption - of the regulatory capital ratio $\theta$.

An increase in economic activity has a positive impact on the level of capital held by the bank. An improvement in macroeconomic conditions increases the expected loan demand next period and the probability that the capital constraint will become binding. The response of banks is to increase capital to keep profits at their maximum. The capital held by banks is therefore procyclical, in the sense that it follows the level of expected loan demand, which is assumed to depend on economic conditions.

\section{Extension to the model and results}

Two key features - and limitations - of the C-C model are that loans, which have a one-period maturity, are always repaid in full and that the capital constraint is independent of macroeconomic conditions. But what is interesting is the link between macroeconomic activity, loan defaults (write-offs) and asset risk-weights. I therefore introduce two extensions. First, I consider the possibility that bank borrowers can default on their principal payment. Moreover, the proportion of defaulted debt is assumed to be a negative function of current macroeconomic conditions, ie write-offs are higher when economic conditions are bad than when they are good. Bank loan defaults translate into an extra cost term in the banks' profit function. As will become clear, unlike in $\mathrm{C}-\mathrm{C}$, the marginal cost curve will now shift downwards (upwards) as macroeconomic conditions improve (worsen). In other words, economic conditions affect loan supply as well as demand. The second assumption I introduce is that the risk-weight assigned to loans in the capital adequacy ratio is not constant, as in $\mathrm{C}-\mathrm{C}$, but is a decreasing function of current macroeconomic conditions, as implied by Basel II. 
As regarding the first assumption, there is evidence to support the notion that loan write-offs are higher during recessions. Weak economic conditions are likely to be associated with a deterioration in asset quality as borrowers' financial health weakens. Chart 1 shows the aggregate annual net write-off to loan ratio, constructed from data published on the public accounts of the major UK banks, and the (inverted) annual UK output gap ${ }^{(15)}$ over the period 1978-2000. The two series seem to follow the same pattern, with write-offs following the output gap with a lag.

\section{Chart 1: Write-off/loan ratio and UK (inverted) output gap}

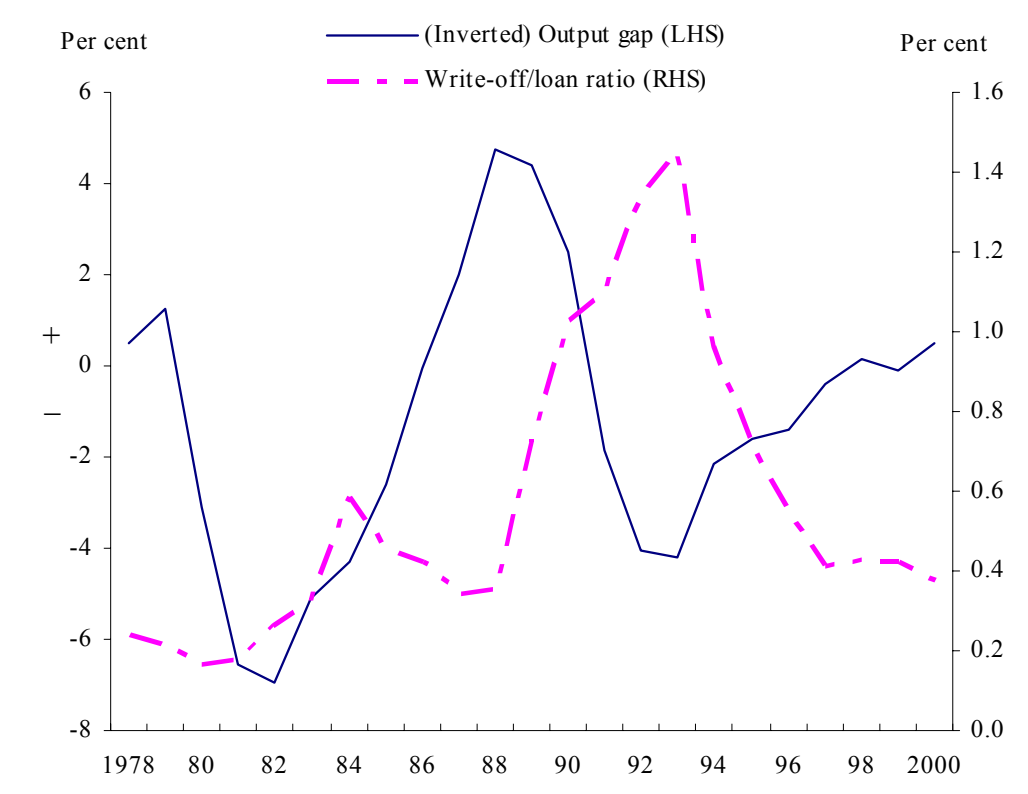

Sources: Bank of England; OECD Economic Outlook.

Chart 2 shows the annual aggregate net write-off to loan ratio together with (inverted) UK GDP growth rate from 1988 to 2002 . The chart confirms the intuition of a countercyclical movement in loan losses for the United Kingdom. Moreover, the negative correlation between bank losses and the business cycle does not seem to be a unique feature of the UK economy. Borio, Furfine and Lowe (2001) show evidence of a cyclical pattern of bank provisions for loan losses in many OECD countries, with a particularly strong link between the provision to asset ratio and the output gap in Australia, Sweden, Norway, Japan and Spain.

The assumption made in this paper is that write-offs react to the current value of $M$, which can be thought of as a proxy for GDP. However, they depend on past macroeconomic conditions as well,

(15) As calculated by the OECD. 
given that $M$ is described by an autoregressive process.

\section{Chart 2: Write-off/loan ratio and UK GDP growth rate}

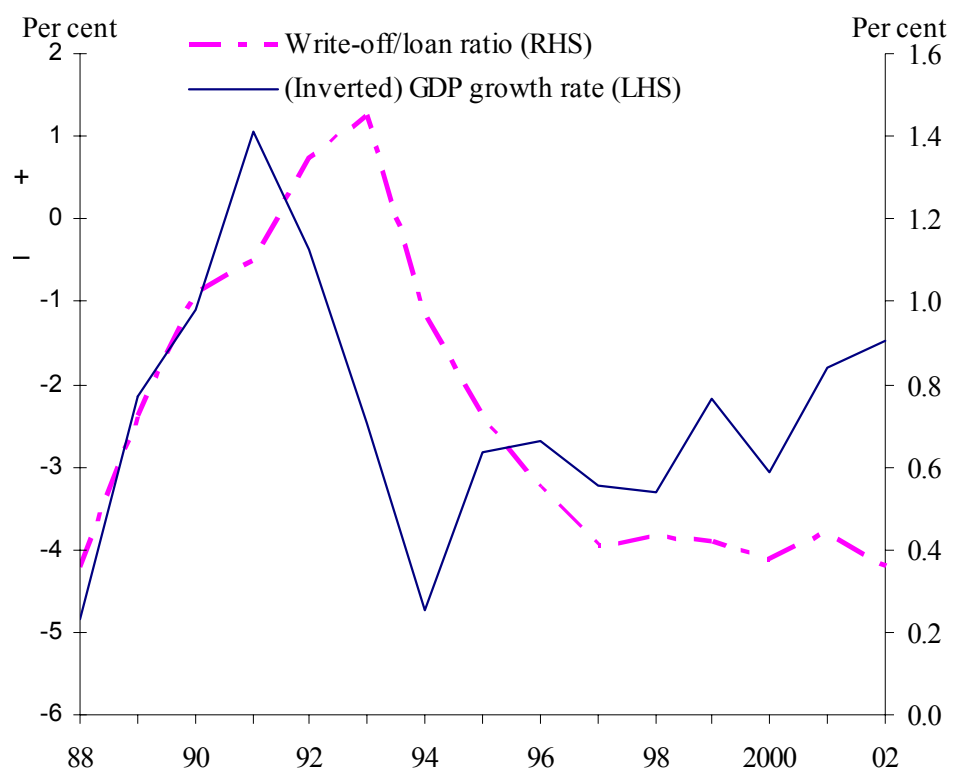

Source: Bank of England.

The second assumption introduced here is that risk-weights vary with macroeconomic conditions. In the revised Basel Accord banks are given the choice between two methodologies for calculating their minimum capital requirements. Under the so-called standardised approach, exposures included in banks' retail portfolios would maintain a constant risk-weight ${ }^{(16)}$ while external credit assessments, such as credit scores by rating agencies, would be used to construct the risk-weights for claims on sovereigns, banks, and corporates. In assessing a borrower's creditworthiness, the major rating agencies aim at maintaining a stable rating through the business cycle. There is, however, evidence that credit ratings show a cyclical pattern with more downgrades than upgrades during recessions (see, for example, Nickell, Perraudin and Varotto (2000)). Under the alternative method (the internal ratings based approach) some banks will use their own credit ratings to determine capital requirements. This approach might induce more cyclicality in risk-weights. Most internal rating systems use a short-term horizon to measure risk. In particular, borrowers' probability of default, which is one of the terms in the formula for risk-weights, is determined over

(16) Claims in the retail portfolio, which includes small businesses, credit cards, personal loans and leases, may be risk-weighted at $75 \%$, with the exception of loans secured by mortgages on residential property and past due loans. Claims secured by residential property will be risk-weighted at $35 \%$, while past due loans, which will have a risk-weight of either $100 \%$ or $150 \%$, depending on what percentange of the outstanding amount of the loan is covered by specific provisions. 
a one-year period and borrowers are assigned to rating grades using models such as Moody's KMV. ${ }^{(17)}$ A number of papers, including Catarineu-Rabell et al (2003) and Kashyap and Stein (2004), have shown that this introduces considerable cyclicality in risk-weighted assets. In its third Consultative Paper (CP3), ${ }^{(18)}$ the Basel Committee has proposed flatter risk-weight curves for small and medium enterprises ${ }^{(19)}$ as a way to address the concern that procyclicality will increase under the IRB approach. This initiative will certainly dampen the volatility in capital ratios but probably not eliminate it. Indeed, evidence presented in Kashyap and Stein (2004) among others is based on the revised curves for corporate and SME credit. Our assumption reflects the idea that, under the new Capital Accord, risk-weights might become more closely related to current macroeconomic conditions.

\subsection{Bank loan quantity and price response to changing macroeconomic conditions}

\subsubsection{Case I: banks' loan losses depend on macroeconomic conditions and asset risk-weights are constant (Basel I)}

In what follows I present the result of the model under the assumption that bank loans may not be repaid, ie that borrowers can default. The proportion of defaulted debt is a negative function of current macroeconomic conditions, ie write-offs are higher when economic conditions are bad than when they are good. The risk-weight on loans is constant, as in Basel I.

In the model banks operate in an oligopolistic market for (risky) loans and invest in a safe asset (treasury securities) for liquidity purposes. I solve the profit maximisation problem for a monopolist bank and, in the appendix, derive the condition under which banks co-operate and equally share the profits of the industry. ${ }^{(20)}$

The capital constraint that a bank faces when maximising its profits is the following:

(17) See the discussion paper by the Basel Committee on Banking Supervision (2000) for a survey on banks' Internal Ratings Systems.

(18) See BCBS (2003).

(19) For any given type of asset, these curves describe the relationship between the capital charge and the probability of default.

(20) The condition is identical to the one obtained in C-C. 


$$
\theta \leq \frac{q_{t-1} s_{t}+b_{t}}{w_{L} L_{t}+w_{T} T_{t}}
$$

where the risk-weight on treasuries $\left(w_{T}\right)$ is assumed to be zero and the one on loans $\left(w_{L}\right)$ is set equal to 1 .

The bank faces a downward sloping demand curve and equates marginal revenue to marginal cost to find the optimal quantity of loans $L_{t}$ and the optimal loan rate $r_{t}^{L}$, in each period $t$.

The bank's profits are given by the following expression:

$$
\pi_{t}=r_{t}^{L} L_{t}+r_{t}^{T} T_{t}-c_{L} L_{t}-r_{t}^{D} D_{t}-c_{D} D_{t}-\frac{r_{t}^{p}}{2 \bar{D}}(\bar{D}-T)^{2}-\delta\left(M_{t}\right) L_{t}
$$

where $\delta\left(M_{t}\right) L_{t}$ represents defaulted loans. The default rate $\delta^{(21)}$ varies between 0 and 1 and increases when macroeconomic conditions deteriorate, ie $0 \leq \delta\left(M_{t}\right) \leq 1$ and $\frac{\partial \delta\left(M_{t}\right)}{\partial M_{t}}<0$.

The objective is to analyse the impact on banks' decisions of macroeconomic conditions when losses depend on macroeconomic conditions and a risk-insensitive capital adequacy constraint, described in (11), is in place. In order to achieve this, I need to solve for the optimal bank allocation of assets between loans and treasuries, and liabilities between deposits and total capital (equity plus subordinated debt). This is shown in the appendix. It is possible then to analyse how bank capital and the quantity and price of loans are affected by changes in macroeconomic conditions.

Proposition 1 Under the assumption of positive loan losses and constant asset risk-weights, banks raise (decrease) their capital holdings in response to a positive (negative) shock in the current level of economic activity.

The proof of this proposition is given in the appendix. This result is similar to the one obtained in $\mathrm{C}-\mathrm{C}$ but here bank capital is more procyclical. This is because lending is more procyclical in a model with loan losses, as will be shown in the next propositions.

(21) $\delta$ corresponds to the loss given default (LDG). 
We proceed now to establish the impact of changes in $M_{t}$ on loans and loan rates. We present first the results under a non-binding capital constraint and then under a binding constraint.

When $\lambda_{t}=0$, ie the constraint does not bind, then:

$$
\begin{gathered}
\frac{\partial L_{t+j}}{\partial M_{t}}=\frac{1}{2} l_{2} \rho_{M}^{j}-\frac{\rho_{M}^{j} l_{1}}{2} \frac{\partial \delta\left(M_{t+j}\right)}{\partial M_{t+j}} \\
\frac{\partial r_{t+j}^{L}}{\partial M_{t}}=\frac{1}{2 l_{1}} l_{2} \rho_{M}^{j}+\frac{\rho_{M}^{j}}{2} \frac{\partial \delta\left(M_{t+j}\right)}{\partial M_{t+j}}
\end{gathered}
$$

Proposition 2 When the capital constraint is non-binding, bank loans increase as a result of an improvement in macroeconomic activity, while the loan rate can either increase or decrease depending on the parameters characterising the loan demand function and the loan default rate.

The proof of this proposition follows directly from (13), (14) and the condition $\frac{\partial \delta\left(M_{t+j}\right)}{\partial M_{t+j}}<0$.

When macroeconomic conditions improve, loan demand shifts to the right and, because default rates decrease, the marginal cost curve shifts downwards. ${ }^{(22)}$ The marginal cost curve moves downwards (from $M C_{1}$ to $M C_{2}$ in Figure 2) and banks find it profitable to increase the supply of loans. The rate charged on loans, however, can either increase or decrease depending on the parameters characterising the loan demand and on the loan default rate. It is important to notice that, when accounting for the possibility of loan defaults, the loan supply increases by more than in the C-C model - to $L_{2}$ rather than $L_{2, C C}$ in Figure 2 - in response to better macroeconomic conditions, because the marginal cost curve shifts downwards at the same time the demand (and the marginal revenue) curve shifts upwards. ${ }^{(23)}$

(22) The derivative of the marginal cost curve with respect to $M_{t}$ is described by the following expression:

$$
\frac{\partial M C(t+j)}{\partial M_{t}}=\frac{\partial \delta(t+j)}{\partial M_{t+j}} \rho_{M}^{j}<0
$$

(23) It should be noted that the impact of a change in macroeconomic conditions dies out over time, since $\rho_{M}^{j}<1$, ie the effect of the current value of $M$ on future macroeconomic conditions declines over time. 
Figure 2: Loan market equilibrium when the capital constraint is non-binding

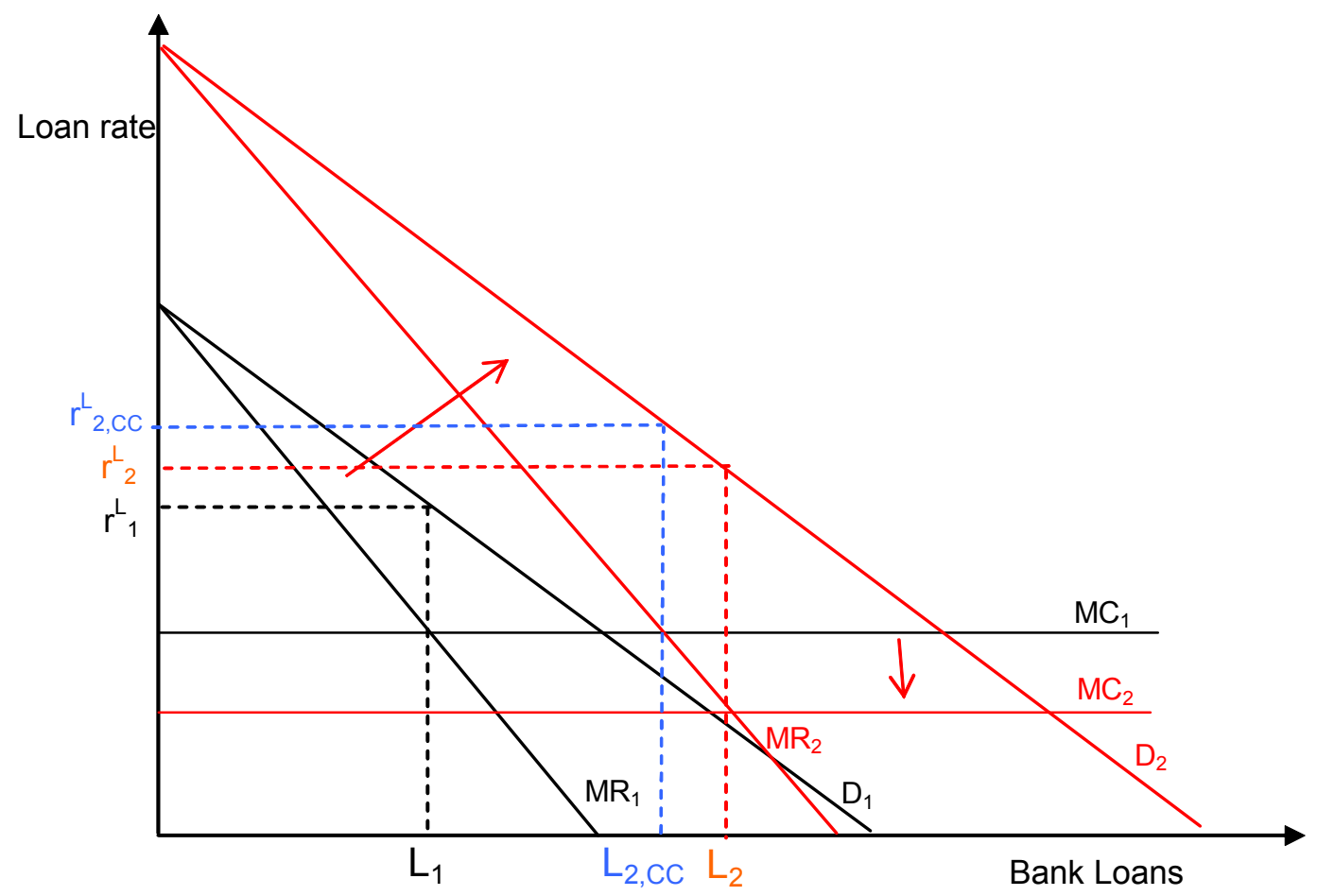

I consider now the case in which the capital constraint binds, ie $\lambda_{t}>0$. In this case loan supply is determined by the capital adequacy constraint and is equal to

$$
L_{t}^{*}=\frac{q_{t-1} s_{t}+b_{t}}{\theta}
$$

while the loan rate response to changes in macroeconomic activity is:

$$
\frac{\partial r_{t}^{L}}{\partial M_{t}}=\frac{l_{2}}{l_{1}}
$$

Proposition 3 When the capital constraint is binding, current bank lending does not change in response to an improvement in macroeconomic activity. The loan rate however increases as a consequence of a higher loan demand.

The proof of this proposition follows immediately from (16) and (17). 
An increase in $M_{t}$ causes an upward movement of the loan demand and a downward movement of the marginal cost curve (see Figure 3). Banks are willing to increase their loan supply but they are not are able to do so because they are capital-constrained. The loan rate increases up to $r^{L}$.

\section{Figure 3: Loan market equilibrium with a binding capital constraint}

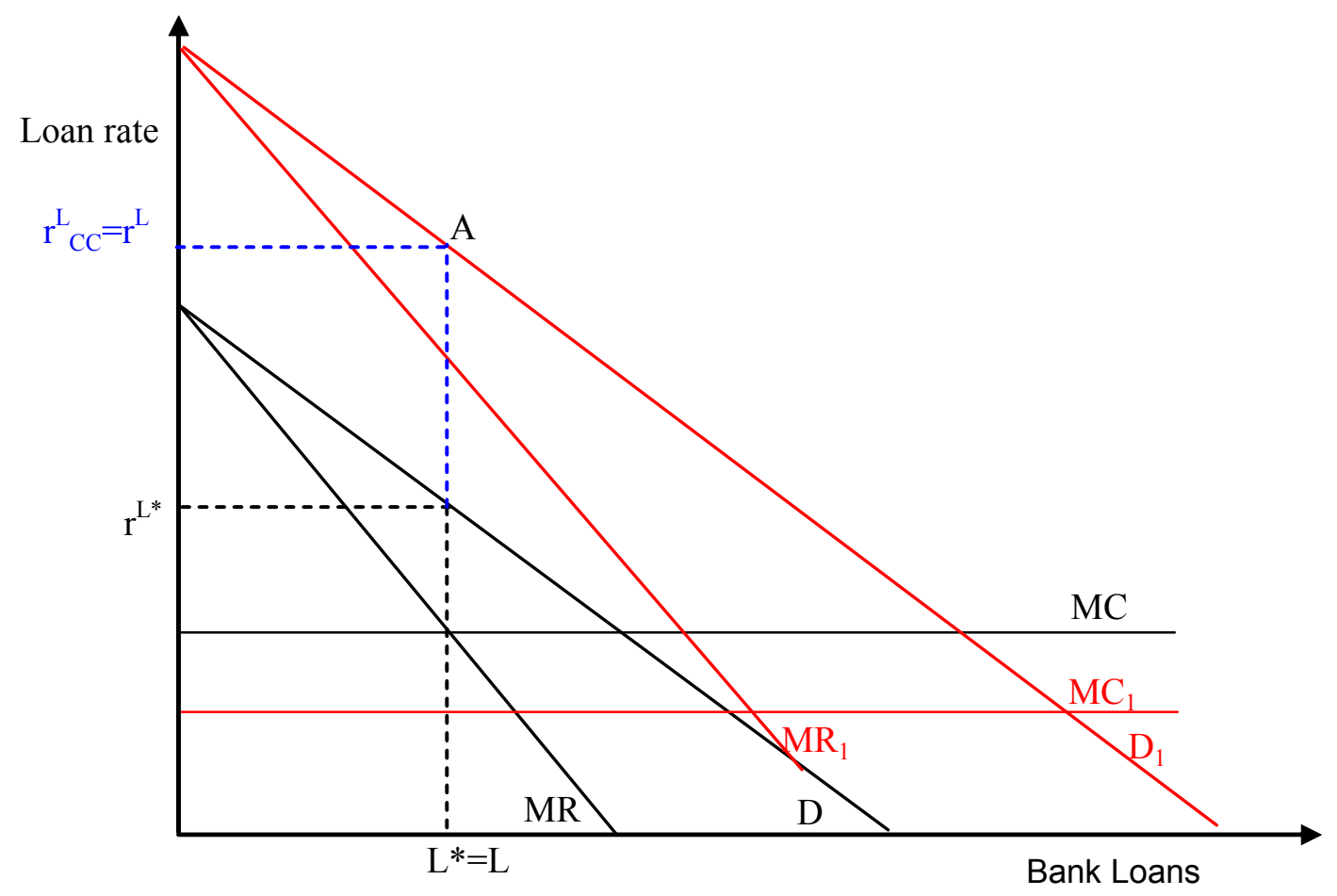

3.1.2 Case II: banks' loan losses and asset risk-weights depend on macroeconomic conditions (Basel II)

In this section analogous propositions to the ones in the previous section will be derived for a model where both loan losses and loan risk-weights are a function of macroeconomic conditions $M_{t}$.

The capital constraint is now described by the following expression:

$$
\theta \leq \frac{q_{t-1} s_{t}+b_{t}}{w\left(M_{t}\right) L_{t}+w_{T} T_{t}}
$$

where the risk-weight on treasuries $\left(w_{T}\right)$ is again assumed to be zero and the one on loans is a 
decreasing function of current macroeconomic conditions, ie $\frac{\partial w\left(M_{t}\right)}{\partial M_{t}}<0$.

Proposition 4 Under the assumption of positive loan losses and a risk-sensitive capital constraint, banks can either raise or lower their capital holdings in response to a positive shock in the current level of economic activity. Their choice depends on the effect that the change in $M_{t}$ has on the likelihood of the capital constraint binding next period.

The proof of this proposition is given in the appendix. This result is in contrast to the Basel I model and provides an interesting implication for the policy debate about the risk that the new capital standards may exacerbate the cyclicality of bank lending. If the critical shock to loan demand, $\varepsilon_{L, t+1}^{*}{ }^{(24)}$ decreases when $M_{t}$ increases, ie if the likelihood that the capital constraint will bind next period increases, then banks will choose to hold more capital to be able to grant more loans next period. However, it is possible that $\frac{\partial \varepsilon_{L, t+1}^{*}}{\partial M_{t}}>0$, and that bank capital decreases (see the appendix). The reason for this possibility is that, in the Basel II model, better macroeconomic conditions have two counteracting effects on bank capital. On the one hand, since banks expect a higher loan demand in the future, they want to be able to supply more loans. In order to be able to increase their lending, they need to hold more capital. At the same time though, banks expect lower risk-weights and, therefore, a higher capital to asset ratio, which makes it less likely that the capital constraint will bind. Since holding capital entails a deadweight cost for banks, they have an incentive to reduce the amount of capital. If the second effect dominates, banks will choose to hold less capital. To summarise, once allowance is made for varying risk-weights in the capital ratio, the impact of the current macroeconomic conditions on banks' capital holdings is ambiguous. In contrast to the model presented in the previous paragraph, a positive shock to $M_{t}$ does not necessarily induce banks to increase capital.

I turn now to the effect of a shock to $M_{t}$ on bank loans and the loan rate, and analyse both cases: when the capital constraint is slack and when it is binding.

When $\lambda_{t}=0$, ie the constraint does not bind, then:

(24) In the appendix $\varepsilon_{L, t+1}^{*}$ is derived as the critical shock to loan demand at time $t+1$ such that the capital constraint just binds. 


$$
\begin{gathered}
\frac{\partial L_{t+j}}{\partial M_{t}}=\frac{1}{2} l_{2} \rho_{M}^{j}-\frac{\rho_{M}^{j} l_{1}}{2} \frac{\partial \delta\left(M_{t+j}\right)}{\partial M_{t+j}} \\
\frac{\partial r_{t+j}^{L}}{\partial M_{t}}=\frac{1}{2 l_{1}} l_{2} \rho_{M}^{j}+\frac{\rho_{M}^{j}}{2} \frac{\partial \delta\left(M_{t+j}\right)}{\partial M_{t+j}}
\end{gathered}
$$

Proposition 5 Under the same assumptions of Proposition 4, and when the capital constraint is non-binding, bank loans increase as a result of an improvement in macroeconomic activity. The loan rate can either increase or decrease depending on the parameters characterising the loan default rate and the loan demand function.

The proof of this proposition follows directly from (19), (20) and the condition $\frac{\partial \delta\left(M_{t+j}\right)}{\partial M_{t+j}}<0$.

Clearly, when the capital constraint is non-binding, the models with constant and non-constant risk-weights yield the same results as regards extension of loans. The impact on the quantity and price of loans of a positive shock to $M_{t}$ can be seen in Figure 2 above.

I consider now the case in which the capital constraint binds, ie $\lambda_{t}>0$. By taking the first derivative of (A-19) in the appendix with respect to $M_{t}$, I obtain:

$$
\frac{\partial L_{t}^{*}}{\partial M_{t}}=-\frac{q_{t-1} s_{t}+b_{t}}{\theta\left[w\left(M_{t}\right)\right]^{2}} \frac{\partial w\left(M_{t}\right)}{\partial M_{t}}
$$

while the loan rate response to changes in macroeconomic activity is:

$$
\frac{\partial r_{t}^{L}}{\partial M_{t}}=\frac{l_{2}}{l_{1}}+\frac{q_{t-1} s_{t}+b_{t}}{\theta l_{1}\left[w\left(M_{t}\right)\right]^{2}} \frac{\partial w\left(M_{t}\right)}{\partial M_{t}}
$$

Proposition 6 Under the same assumptions of Proposition 4, and when the capital constraint is binding, current bank lending increases in response to an improvement in macroeconomic activity. The loan rate can either increase or decrease depending on the parameters characterising the loan demand and the risk-weights. 
The proof of this proposition follows from (21), (22) and the assumption $\frac{\partial w\left(M_{t+j}\right)}{\partial M_{t+j}}<0$.

An increase in $M_{t}$ induces both a slackening of the capital constraint and an upward shift of the loan demand (see Figure 4). Banks are willing to increase their loan supply and are able to do so because their capital ratio has increased. The direction of the change in the loan rate depends on the elasticity of loan demand with respect to the loan rate, and the sensitivity of loan demand and the risk-weight to macroeconomic conditions. The higher the sensitivity of loan demand to $M_{t}$ (ie the bigger the parameter $l_{2}$ ), the more the loan rate tends to increase. The higher the elasticity of loan demand and the sensitivity of risk-weights to $M_{t}$ (ie the bigger $l_{1}$ and $\left.\frac{\partial w\left(M_{t}\right)}{\partial M_{t}}\right)$, the more the loan rate tends to decrease. At the limit, if the positive shock to macroeconomic conditions makes the capital constraint slack, loan supply goes from $L^{*}$ to $L$ and the loan rate from $r^{L^{*}}$ to $r^{L}$ in Figure 4. If the capital constraint still binds, the equilibrium loan quantity will be somewhere between $L^{*}$ and $L$ and the loan rate between $r_{C C}^{L}$ and $r^{L}$. This is in contrast to the Basel I model, where loans would remain at $L^{*}$ throughout this exercise and the loan rate would respond by moving from $r^{L^{*}}$ to $r_{C C}^{L}$.

\section{Figure 4: Loan market equilibrium when the bank capital constraint is binding}

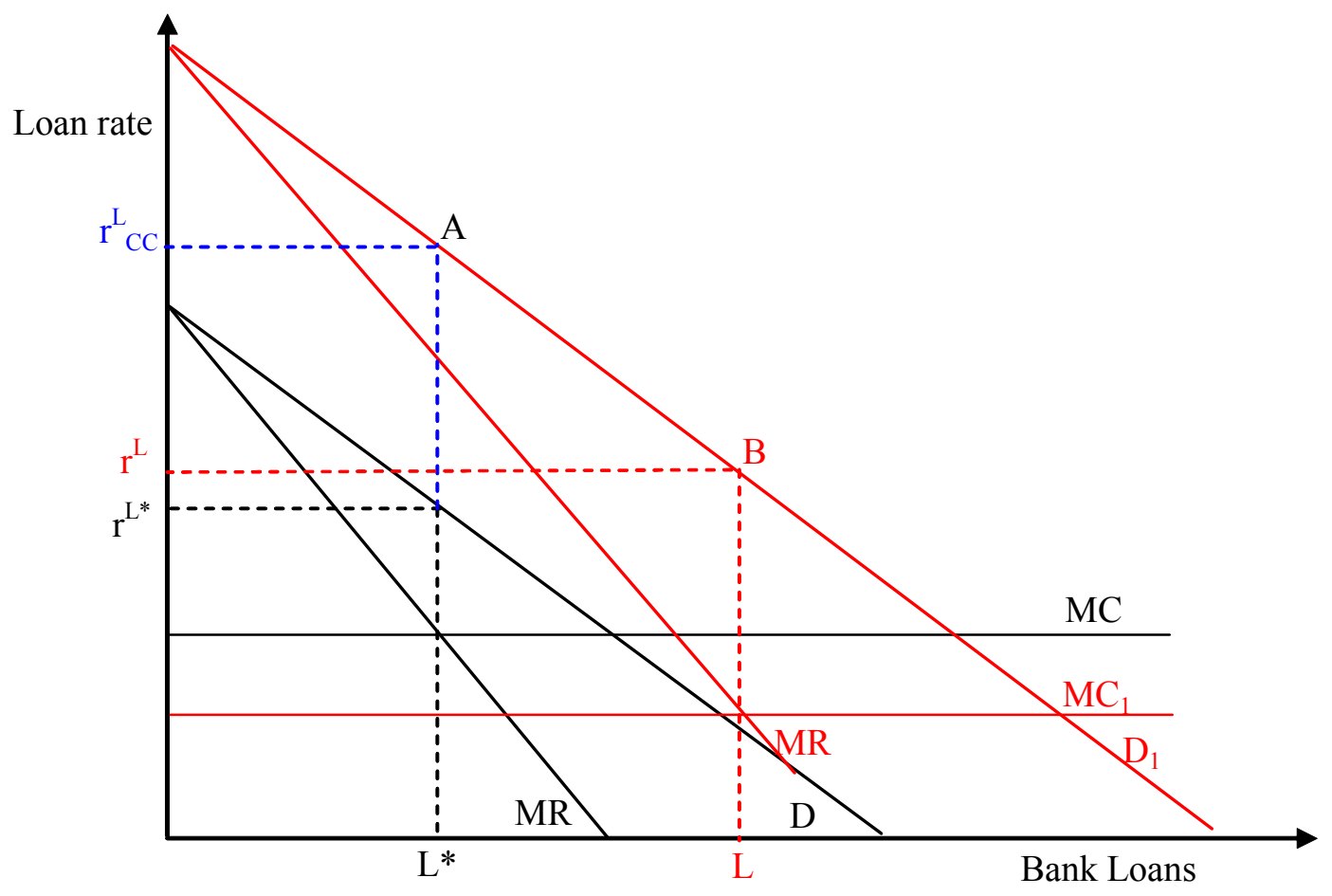

Finally, I analyse the effect of a current shock to macroeconomic conditions on bank loans and 
loan rates in future periods. This impact is analogous to the one on current loans and loan rates, ie it depends on whether the capital constraint binds or not in future periods. If the capital constraint is slack, the response of loans and loan rates in period $j \geq 1$ to a current macroeconomic shock is described by Proposition 4 but the impact of the shock dies out over time, since $\rho_{M}^{j}<1$.

If the capital constraint binds in future periods, the response of loans and loan rates to a change in $M_{t}$ is described by:

$$
\frac{\partial L_{t+j}^{*}}{\partial M_{t}}=\frac{\rho_{M}^{j-1}}{\theta w\left(M_{t+j}\right)}\left\{\frac{\partial\left(q_{t-1+j} s_{t+j}+b_{t+j}\right)}{\partial M_{t-1+j}}-\frac{\rho_{M}\left(q_{t-1+j} s_{t+j}+b_{t+j}\right)}{w\left(M_{t+j}\right)} \frac{\partial w\left(M_{t+j}\right)}{\partial M_{t+j}}\right\}
$$

and

$$
\frac{\partial r_{t+j}^{L}}{\partial M_{t}}=\frac{l_{2} \rho_{M}^{j}}{l_{1}}+\frac{\rho_{M}^{j-1}}{\theta l_{1}\left[w\left(M_{t+j}\right)\right]^{2}}\left\{\rho_{M}\left(q_{t-1+j} s_{t+j}+b_{t+j}\right) \frac{\partial w\left(M_{t+j}\right)}{\partial M_{t+j}}-\frac{\partial\left(q_{t-1+j} s_{t+j}+b_{t+j}\right)}{\partial M_{t+j-1}}\right\}
$$

Therefore, future bank loans can either increase or decrease in response to a positive shock to current macroeconomic conditions depending on the relative magnitudes of the terms in the right-hand side of equation (23). Recall that Proposition 4 tells us that under Basel II capital does not necessarily increase in response to a positive shock to $M_{t}$. If capital decreases in response to a positive shock to macroeconomic conditions, loans can decrease as well, provided that the first term in the curly brackets in (23) is bigger than the second term, ie that the effect of the shock on capital dominates the effect of the shock on loan risk-weights. Finally, the sign of the change in loan rates is undetermined, as it can be seen from equation (24).

As a summary of the results of the paper, Table A below shows the effect of a positive shock to macroeconomic conditions on banks' lending under the two capital adequacy regimes (Basel I and Basel II). 
Table A: Responses to a positive shock to macroeconomic conditions

\begin{tabular}{|c|c|c|c|}
\hline \multirow{3}{*}{ Basel I, non-binding capital constraint } & Loans & Loan rate & Bank capital \\
\hline & + & + & + \\
\hline & $=$ & ++ & + \\
\hline \multirow{2}{*}{ Basel II, non-binding capital constraint } & + & + & $\begin{array}{l}\text { Undetermined, } \\
\text { lower than in the } \\
\text { Basel I model }\end{array}$ \\
\hline & + & $\begin{array}{l}\text { Undetermined, } \\
\text { lower than in the } \\
\text { Basel I model }\end{array}$ & $\begin{array}{l}\text { Undetermined, } \\
\text { lower than in the } \\
\text { Basel I model }\end{array}$ \\
\hline
\end{tabular}

In both versions of the model presented here, there are two cases: with the current capital constraint binding, and with it non-binding. In the Basel I model, both bank loans and loan rate increase in response to a positive shock to $M_{t}$, when the capital constraint is not binding. If instead the capital constraint binds, an upward shift of the loan demand will induce an increase in the loan rate, which will be higher than in the unconstrained case, but leave the loan supply unchanged. Moreover, since a positive shock to macroeconomic conditions increases the likelihood that the capital will be binding in the future, banks increase the amount of capital they hold.

In the Basel II model, a shock to current macroeconomic conditions affects not only the loan demand but also the risk-weights in banks' capital to asset ratios. If the capital constraint is slack, bank loans increase by the same amount than in the Basel I model. If the capital constraint is binding, then, unlike under Basel I, banks can still expand their credit supply, even though by less than if the capital is non-binding. They are able to do so because a positive shock to macroeconomic conditions induces lower risk-weights and therefore a slackening of the capital constraint. The loan rate can either increase or decrease, depending on the relative size of the change in loan demand and capital ratio. Analogously, a negative shock to macroeconomic conditions results in a possibly greater reduction of credit than in the Basel I model because of both a downward shift of the loan demand and a tightening of the capital constraint. 
Moreover, under Basel II, the sign of the change in banks' capital holding is undetermined as a positive shock to $M_{t}$ has two counteracting effects on the equilibrium value of bank capital. On the one hand, a positive macroeconomic shock has a persistent positive effect on loan demand and therefore raises the likelihood of the capital constraint binding in the future. At the same time, however, the capital ratio increases so that the likelihood that the capital constraint will bite becomes lower.

\section{Concluding remarks}

The model by Chami and Cosimano analyses, among other things, the effect of macroeconomic shocks on bank capital holding. Their conclusion is that capital - the numerator in the capital adequacy ratio - is procyclical. An improvement in macroeconomic conditions induces an increase in the loan demand and, as a consequence, an increase in the probability that the capital constraint will become binding. The response of banks is to increase capital to maximise profits. Thus, a bank's capital is procyclical because it changes according to expected loan demand, which is assumed to be a function of the current level of macroeconomic activity.

By extending the model to include loan default and loan risk-weights as variables depending on macroeconomic activity, I introduce two other 'channels' through which economic conditions affect banks' capital and lending. The first channel is active under any capital adequacy regime: empirical evidence supports the assumption that better macroeconomic conditions reduce the loan default rate and thus the loan marginal cost. This implies a greater variability in loan supply than in the C-C economy, where loans are default free.

Under Basel II, a macroeconomic shock will also affect the loan risk-weights in the capital to asset ratio. As a result, the capital constraint might become either tighter, if the shock is negative, or looser, if the shock is positive. Therefore, if banks face a binding capital constraint, they will be able to increase their loan supply in response to better macroeconomic conditions but they might be forced to reduce supply if the shock is negative. By contrast, in the model with constant risk-weights, a shock affects only the loan rate while leaving the loan supply unchanged when the capital constraint binds.

The other implication of risk-sensitive weights à la Basel II is that banks do not necessarily 
increase their capital in response to a positive macroeconomic shock. Similarly, a deterioration of macroeconomic conditions does not necessarily induce banks to decrease their capital. This happens because macroeconomic conditions not only affect loan demand but also banks' capital constraint. Since a positive shock induces a decrease in the asset risk-weights, and thus an increase in capital ratios, banks do not necessarily need to raise new capital to expand their loan supply. Analogously, since a negative shock tightens the capital constraint, a reduction in loan demand does not necessarily induce banks to decrease their capital.

Said differently, under Basel II banks might not have the necessity to maintain the same level of capital during periods of high economic activity as under Basel I. For this reason banks might be more vulnerable to unexpected negative shocks. If the economy falls into a recession or experiences a weakening in its growth, it will be more likely for banks' capital constraint to be binding and thus for credit to be rationed.

These findings may have implications for public policy. Risk-sensitive weights may lead to a greater reduction of credit following a negative macroeconomic shock. Not only will loan demand fall during an economic downturn but banks may be forced to reduce loan supply to satisfy tighter capital requirements. In order to avoid such an eventuality, supervisors may therefore want to encourage banks to maintain a capital buffer (during the periods of strong economic growth) above the one banks would choose voluntarily. Indeed, such an approach has been favoured by the Basel Committee and is recommended under Pillar 2 of the new Accord (the Supervisory Review Process). Under the Supervisory Review Process, banks may in fact be required to hold more capital than the regulatory minimum as a protection against risks, including the potential impact of an economic downturn, which are not fully captured by Pillar 1. Alternatively, cyclicality in capital requirements could be addressed under Pillar 1, eg by adjusting capital requirements in response to changes in macroeconomic conditions, as proposed by Kashyap and Stein (2004) and Gordy and Howells (2004). 


\section{Appendix}

\section{The bank's optimisation problem}

Here I present the model with loan losses and asset risk-weights that depend on macroeconomic conditions.

Banks' balance sheet identity is:

$$
L_{t}+T_{t}=(1-\alpha) D_{t}+q_{t-1} s_{t}+b_{t}
$$

while banks' cash flows are given by (12).

The bank maximisation problem is the following: ${ }^{(25)}$

$$
\begin{gathered}
\max _{r_{t}^{L}, D_{t},\left(q_{t} s_{t+1}+b_{t+1}\right)} v\left(q_{t-1} s_{t}+b_{t}, x_{t}\right)=\left\{\pi_{t}+\lambda_{t}\left[q_{t-1} s_{t}+b_{t}-\theta w\left(M_{t}\right) L_{t}\right]\right. \\
\left.-\tau_{t}\left[q_{t} s_{t+1}+b_{t+1}\right]+E_{t}\left[m_{t, 1} v\left(q_{t} s_{t+1}+b_{t+1}, x_{t+1}\right)\right]\right\}
\end{gathered}
$$

subject to:

$$
\pi_{t}=r_{t}^{L} L_{t}+r_{t}^{T} T_{t}-c_{L} L_{t}-r_{t}^{D} D_{t}-c_{D} D_{t}-\frac{r_{t}^{p}}{2 \bar{D}}(\bar{D}-T)^{2}-\delta\left(M_{t}\right) L_{t}
$$

(25) Given that the 'uses' of cash flow are:

$$
\pi_{t}=-\left[-d_{t} s_{t}-\left(1+r_{t}^{b}\right) b_{t}-q_{t} s_{t}+q_{t} s_{t+1}+b_{t+1}\right]
$$

where $\left(1+r_{t}^{b}\right) b_{t}+q_{t} s_{t}$ is given at time $t$, choosing $\left(q_{t} s_{t+1}+b_{t+1}\right)$ or dividends $d_{t}$ is equivalent. 


$$
\begin{gathered}
L_{t}=l_{0}-l_{1} r_{t}^{L}+l_{2} M_{t}+\varepsilon_{L, t} \\
q_{t} s_{t+1}+b_{t+1}=\left(d_{t}+q_{t}\right) s_{t}+\left(1+r_{t}^{b}\right) b_{t}-\pi_{t} \\
T_{t}=(1-\alpha) D_{t}+q_{t-1} s_{t}+b_{t}-L_{t}
\end{gathered}
$$

The first-order conditions of the maximisation problem (A-2) are:

$$
\begin{aligned}
& r_{t}^{L}: \frac{\partial \pi_{t}}{\partial r_{t}^{L}}\left[1+\tau-E_{t}\left\{\int_{\underline{L}}^{\bar{L}} m_{t, 1}\left(\frac{\partial V}{\partial\left(q_{t} s_{t+1}+b_{t+1}\right)}\right) d F\left(\varepsilon_{L, t+1}\right)\right\}\right] \\
& +\lambda_{t} \theta w\left(M_{t}\right) l_{1}=0
\end{aligned}
$$

$$
q_{t} s_{t+1}+b_{t+1}:-\tau+E_{t}\left\{\int_{\underline{L}}^{\bar{L}} m_{t, 1}\left(\frac{\partial V}{\partial\left(q_{t} s_{t+1}+b_{t+1}\right)}\right) d F\left(\varepsilon_{L, t+1}\right)\right\}=0
$$




$$
r_{t}^{T}(1-\alpha)-r_{t}^{D}-c_{D}+(1-\alpha) \frac{r_{t}^{p}}{\bar{D}}(\bar{D}-T)=0
$$

$$
\theta w\left(M_{t}\right) L_{t}-q_{t-1} s_{t}+b_{t}<0
$$

From the above conditions and the loan demand (A-4) I obtain the optimal bank loan supply and loan rate:

$$
\begin{aligned}
& L_{t}=\frac{1}{2}\left(l_{0}+l_{2} M_{t}+\varepsilon_{L, t}\right)-\frac{l_{1}}{2}\left(c_{L}+\frac{r_{t}^{D}+c_{D}}{1-\alpha}+\delta\left(M_{t}\right)\right) \\
& r_{t}^{L}=\frac{1}{2 l_{1}}\left[l_{0}+l_{2} M_{t}+\varepsilon_{L, t}\right]+\frac{1}{2}\left[c_{L}+\frac{r_{t}^{D}+c_{D}}{1-\alpha}+\delta\left(M_{t}\right)\right]
\end{aligned}
$$

From (A-11), I obtain the following expression for the treasury bonds:

$$
T_{t}=\bar{D}+\frac{\bar{D}}{r_{t}^{p}}\left(r_{t}^{T}-\frac{r_{t}^{D}+c_{D}}{1-\alpha}\right)
$$

From the balance-sheet identity (A-1), I get the deposits:

$$
D_{t}=\frac{1}{1-\alpha}\left[\bar{D}+L_{t}-\left(q_{t-1} s_{t}+b_{t}\right)\right]+\frac{\bar{D}}{r_{t}^{p}(1-\alpha)}\left(r_{t}^{T}-\frac{r_{t}^{D}+c_{D}}{1-\alpha}\right)
$$

And I finally obtain bank profits: 


$$
\begin{aligned}
\pi_{t}= & \frac{1}{4 l_{1}}\left\{\left(l_{0}+l_{2} M_{t}+\varepsilon_{L, t}\right)^{2}-\left(l_{1}\right)^{2}\left(c_{L}+\frac{r_{t}^{D}+c_{D}}{1-\alpha}+\delta\left(M_{t}\right)\right)^{2}\right\} \\
& -\left(c_{L}+\frac{r_{t}^{D}+c_{D}}{1-\alpha}+\delta\left(M_{t}\right)\right)\left[\frac{1}{2}\left(l_{0}+l_{2} M_{t}+\varepsilon_{L, t}\right)-\frac{l_{1}}{2}\left(c_{L}+\frac{r_{t}^{D}+c_{D}}{1-\alpha}+\delta\left(M_{t}\right)\right)\right] \\
& +\frac{r_{t}^{D}+c_{D}}{1-\alpha}\left(q_{t-1} S_{t}+b_{t}\right)+\frac{\bar{D}}{2 r_{t}^{p}}\left(r_{t}^{T}-\frac{r_{t}^{D}+c_{D}}{1-\alpha}\right)^{2}+\bar{D}\left(r_{t}^{T}-\frac{r_{t}^{D}+c_{D}}{1-\alpha}\right)
\end{aligned}
$$

When the total capital constraint is binding, ie $\lambda_{t}>0$, the optimal bank loans are given by the following expression:

$$
L_{t}^{*}=\frac{q_{t-1} s_{t}+b_{t}}{\theta w\left(M_{t}\right)}
$$

By equating the loan supply and demand, I get the equilibrium loan rate:

$$
r_{t}^{L^{*}}=\frac{1}{l_{1}}\left(l_{0}+l_{2} M_{t}+\varepsilon_{L, t}\right)-\frac{q_{t-1} s_{t}+b_{t}}{l_{1} \theta w\left(M_{t}\right)}
$$

The amount of treasuries is unaffected by the binding capital constraint:

$$
T_{t}=\bar{D}+\frac{\bar{D}}{r_{t}^{p}}\left(r_{t}^{T}-\frac{r_{t}^{D}+c_{D}}{1-\alpha}\right)
$$

while deposits are now equal to:

$$
D_{t}=\frac{1}{1-\alpha}\left[\bar{D}+L_{t}^{*}-\left(q_{t-1} s_{t}+b_{t}\right)\right]+\frac{\bar{D}}{r_{t}^{p}(1-\alpha)}\left(r_{t}^{T}-\frac{r_{t}^{D}+c_{D}}{1-\alpha}\right)
$$

Finally, bank profits are now described by the expression below: 


$$
\begin{aligned}
\pi_{t}= & \frac{\left(q_{t-1} s_{t}+b_{t}\right)}{\theta w\left(M_{t}\right)}\left[\frac{1}{l_{1}}\left(l_{0}+l_{2} M_{t}+\varepsilon_{L, t}-\frac{q_{t-1} s_{t}+b_{t}}{\theta w\left(M_{t}\right)}\right)-\left(c_{L}+\frac{r_{t}^{D}+c_{D}}{1-\alpha}+\delta\left(M_{t}\right)\right)\right] \\
& +\frac{r_{t}^{D}+c_{D}}{1-\alpha}\left(q_{t-1} s_{t}+b_{t}\right)+\frac{\bar{D}}{2 r_{t}^{p}}\left(r_{t}^{T}-\frac{r_{t}^{D}+c_{D}}{1-\alpha}\right)^{2}+\bar{D}\left(r_{t}^{T}-\frac{r_{t}^{D}+c_{D}}{1-\alpha}\right)
\end{aligned}
$$

\section{Proof of Proposition 1}

In order to prove Proposition 1, which refers to the case where risk-weights are constant, I set $w\left(M_{t}\right)=1$ and derive the relevant results.

Condition (A-10) describes the optimal capital holdings as an implicit function of the other variables in the bank's maximisation problem. I need a few steps before being able to use the implicit function theorem. First I solve for the critical shock to the loan demand, $\varepsilon_{L, t}^{*}$, such that the total capital constraint will just bind, ie $L_{t}=L_{t}^{*}$. To do so, I equate the optimal loans from the two problems (with $\lambda_{t}=0$ and $\lambda_{t}>0$ ) and get:

$$
\varepsilon_{L, t}^{*}=2 \frac{q_{t-1} s_{t}+b_{t}}{\theta}-\left(l_{0}+l_{2} M_{t}\right)+l_{1}\left(c_{L}+\frac{r_{t}^{D}+c_{D}}{1-\alpha}+\delta\left(M_{t}\right)\right)
$$

I can obtain $\lambda_{t}^{*}$, the critical shadow value of capital from the f.o.c. (A-7):

$$
\lambda_{t}^{*} \theta l_{1}=l_{1} r_{t}^{L^{*}}-L_{t}^{*}-l_{1}\left(c_{L}+\frac{r_{t}^{D}+c_{D}}{1-\alpha}+\delta\left(M_{t}\right)\right)
$$

Plugging $r_{t}^{L^{*}}$ and $L_{t}^{*}$ into the expression above, I obtain:

$$
\lambda_{t}^{*}=\frac{\varepsilon_{L, t}-\varepsilon_{L, t}^{*}}{\theta l_{1}}
$$

By applying the envelope theorem to the value function in (A-2), I get: 


$$
\begin{aligned}
\frac{\partial V}{\partial\left(q_{t-1} S_{t}+b_{t}\right)} & =\lambda_{t}+\frac{r_{t}^{D}+c_{D}}{1-\alpha} \\
& =\left\{\begin{array}{cr}
\frac{r_{t}^{D}+c_{D}}{1-\alpha} & \text { for } \underline{L} \leq \varepsilon_{L, t} \leq \varepsilon_{L, t}^{*} \\
\frac{r_{t}^{D}+c_{D}}{1-\alpha}+\frac{1}{\theta l_{1}}\left(\varepsilon_{L, t}-\varepsilon_{L, t}^{*}\right) & \text { for } \varepsilon_{L, t}^{*} \leq \varepsilon_{L, t} \leq \bar{L}
\end{array}\right.
\end{aligned}
$$

Thus, by updating the previous expression by one period and plugging it into the optimal condition for total capital, I finally obtain:

$$
\tau-E_{t}\left[m_{t, 1} \frac{r_{t}^{D}+c_{D}}{1-\alpha}\right]-\frac{1}{\theta l_{1}} E_{t}\left\{\int_{\varepsilon_{L, t+1}^{*}}^{L} m_{t, 1}\left(\varepsilon_{L, t+1}-\varepsilon_{L, t+1}^{*}\right) d F\left(\varepsilon_{L, t+1}\right)\right\}=0
$$

Let's denote the left-hand side of (A-28) as $H$. By the implicit function theorem I know that:

$$
\frac{\partial\left(q_{t} s_{t+1}+b_{t+1}\right)}{\partial M_{t}}=-\frac{\partial H / \partial M_{t}}{\partial H / \partial\left(q_{t} s_{t+1}+b_{t+1}\right)}
$$

To calculate $\partial H / \partial M_{t}$, I apply the Leibnitz's rule to (A-28) and get:

$$
\frac{\partial H}{\partial M_{t}}=\frac{1}{\theta l_{1}}\left\{\frac{\partial \varepsilon_{L, t+1}^{*}}{\partial M_{t}} E_{t}\left(\int_{\varepsilon_{L, t+1}^{*}}^{L} m_{t, 1} d F\left(\varepsilon_{L, t+1}\right)\right)\right\}
$$

where

$$
\frac{\partial \varepsilon_{L, t+1}^{*}}{\partial M_{t}}=-l_{2} \rho_{M}+l_{1} \rho_{M} \frac{\partial \delta}{\partial M_{t+1}}
$$

and 


$$
\frac{\partial H}{\partial\left(q_{t} s_{t+1}+b_{t+1}\right)}=\frac{2}{l_{1} \theta^{2}} E_{t}\left(\int_{\varepsilon_{L, t+1}^{*}}^{L} m_{t, 1} d F\left(\varepsilon_{L, t+1}\right)\right)
$$

Therefore, $\operatorname{sign}\left(\frac{\partial\left(q_{t} s_{t+1}+b_{t+1}\right)}{\partial M_{t}}\right)=-\operatorname{sign}\left(\frac{\partial H}{\partial M_{t}}\right) / \operatorname{sign}\left(\frac{\partial H}{\partial\left(q_{t} s_{t+1}+b_{t+1}\right)}\right)$, which is positive since $\frac{\partial \varepsilon_{L, t+1}^{*}}{\partial M_{t}}<0$.

This concludes the proof of Proposition 1.

\section{Proof of Proposition 4}

Condition (A-10) describes the optimal capital holdings as an implicit function of the other variables in the bank's maximisation problem. I need a few steps before being able to use the implicit function theorem. As in the proof of Proposition 1, I solve for the critical shock to the loan demand, $\varepsilon_{L, t}^{*}$ :

$$
\varepsilon_{L, t}^{*}=2 \frac{q_{t-1} s_{t}+b_{t}}{\theta w\left(M_{t}\right)}-\left(l_{0}+l_{2} M_{t}\right)+l_{1}\left(c_{L}+\frac{r_{t}^{D}+c_{D}}{1-\alpha}+\delta\left(M_{t}\right)\right)
$$

I can obtain $\lambda_{t}^{*}$, the critical shadow value of capital from the f.o.c. (A-7):

$$
\lambda_{t}^{*} \theta w\left(M_{t}\right) l_{1}=l_{1} r_{t}^{L^{*}}-L_{t}^{*}-l_{1}\left(c_{L}+\frac{r_{t}^{D}+c_{D}}{1-\alpha}+\delta\left(M_{t}\right)\right)
$$

Plugging $r_{t}^{L^{*}}$ and $L_{t}^{*}$ into the expression above, I obtain:

$$
\lambda_{t}^{*}=\frac{\varepsilon_{L, t}-\varepsilon_{L, t}^{*}}{\theta w\left(M_{t}\right) l_{1}}
$$

By applying the envelope theorem to the value function in (A-2), I get: 


$$
\begin{aligned}
\frac{\partial V}{\partial\left(q_{t-1} S_{t}+b_{t}\right)} & =\lambda_{t}+\frac{r_{t}^{D}+c_{D}}{1-\alpha} \\
& =\left\{\begin{array}{cc}
\frac{r_{t}^{D}+c_{D}}{1-\alpha} & \text { for } \underline{L} \leq \varepsilon_{L, t} \leq \varepsilon_{L, t}^{*} \\
\frac{r_{t}^{D}+c_{D}}{1-\alpha}+\frac{1}{\theta w\left(M_{t}\right) l_{1}}\left(\varepsilon_{L, t}-\varepsilon_{L, t}^{*}\right) & \text { for } \varepsilon_{L, t}^{*} \leq \varepsilon_{L, t} \leq \bar{L}
\end{array}\right.
\end{aligned}
$$

Thus, by updating the previous expression by one period and plugging it into the optimal condition for total capital, I finally obtain:

$$
\tau-E_{t}\left[m_{t, 1} \frac{r_{t}^{D}+c_{D}}{1-\alpha}\right]-\frac{1}{\theta w\left(M_{t+1}\right) l_{1}} E_{t}\left\{\int_{\varepsilon_{L, t+1}^{*}}^{L} m_{t, 1}\left(\varepsilon_{L, t+1}-\varepsilon_{L, t+1}^{*}\right) d F\left(\varepsilon_{L, t+1}\right)\right\}=0
$$

Let's denote the left-hand side of (A-37) as $H$. By the implicit function theorem I know that:

$$
\frac{\partial\left(q_{t} s_{t+1}+b_{t+1}\right)}{\partial M_{t}}=-\frac{\partial H / \partial M_{t}}{\partial H / \partial\left(q_{t} s_{t+1}+b_{t+1}\right)}
$$

To calculate $\partial H / \partial M_{t}$, I apply the Leibnitz's rule to (A-37) and get:

$$
\begin{aligned}
\frac{\partial H}{\partial M_{t}}= & -\frac{1}{\theta l_{1}}\left\{\frac{-\rho_{M} \frac{\partial w}{\partial M_{t+1}}}{\left[w\left(M_{t+1}\right)\right]^{2}} E_{t}\left(\int_{\varepsilon_{L, t+1}^{*}}^{L} m_{t, 1}\left(\varepsilon_{L, t+1}-\varepsilon_{L, t+1}^{*}\right) d F\left(\varepsilon_{L, t+1}\right)\right)\right. \\
& \left.-\frac{1}{w\left(M_{t+1}\right)} \frac{\partial \varepsilon_{L, t+1}^{*}}{\partial M_{t}} E_{t}\left(\int_{\varepsilon_{L, t+1}^{*}}^{L} m_{t, 1} d F\left(\varepsilon_{L, t+1}\right)\right)\right\}
\end{aligned}
$$

where 


$$
\frac{\partial \varepsilon_{L, t+1}^{*}}{\partial M_{t}}=-\frac{2\left(q_{t} s_{t+1}+b_{t+1}\right)}{\theta\left[w\left(M_{t+1}\right)\right]^{2}} \rho_{M} \frac{\partial w}{\partial M_{t+1}}-l_{2} \rho_{M}+l_{1} \rho_{M} \frac{\partial \delta}{\partial M_{t+1}}
$$

and

$$
\frac{\partial H}{\partial\left(q_{t} s_{t+1}+b_{t+1}\right)}=\frac{2}{l_{1}\left[\theta w\left(M_{t+1}\right)\right]^{2}} E_{t}\left(\int_{\varepsilon_{L, t+1}^{*}}^{L} m_{t, 1} d F\left(\varepsilon_{L, t+1}\right)\right)
$$

Therefore, $\operatorname{sign}\left(\frac{\partial\left(q_{t} s_{t+1}+b_{t+1}\right)}{\partial M_{t}}\right)=-\operatorname{sign}\left(\frac{\partial H}{\partial M_{t}}\right)$, which is positive if $\frac{\partial \varepsilon_{L, t+1}^{*}}{\partial M_{t}}<0$.

This concludes the proof of Proposition 4.

\section{Conditions for the banking industry co-operative equilibrium}

To characterise the equilibrium in the banking industry, I need to find the condition under which co-operative (ie monopolistic) loan pricing by banks dominates Bertrand (price) competition. Assuming a symmetric game, each bank earns $\frac{1}{N}$ of the total profits of the industry $\pi_{t}$. Under co-operative behaviour the value of the bank is $v_{t}^{C}$. If a bank charges a lower rate than its competitors, it will get a larger share of the market and make $\pi_{t}^{U}$ (though the cheating bank will not capture the entire market because capital constraints will put a ceiling on the amount of loans it can supply). However, other banks react by following Bertrand competition such that the penalty for the cheating bank would be equal to the loss of the co-operative profits, $E_{t}\left[m_{t+1} v_{T+1}^{c}\right]$. Therefore, banks co-operate as long as the profits yielded by charging a lower rate then the competitors is not higher than those obtained by co-operating.

C-C describe a possible equilibrium strategy as follows: each bank charges the monopoly loan rate, raises $\frac{1}{N}$ of the industry capital $q_{t-1} s_{t}+b_{t}$, supplies $\frac{1}{N}$ of total loans and earns $\frac{1}{N}$ of the industry profits, as long as no other bank deviates from this strategy. If a bank deviates by setting the loan rate equal to $r_{t}^{L}-\eta$, where $r_{t}^{L}$ is the monopoly rate and $\eta$ is positive and small, the benefit from loan rate cutting is restricted by the regulatory constraint on loans $\frac{1}{N \theta w\left(M_{t}\right)}\left(q_{t-1} s_{t}+b_{t}\right)$. Said differently, when the capital constraint is binding, there is no benefit from undercutting, and when the capital constraint is slack the additional sales are only $\frac{1}{N \theta w\left(M_{t}\right)}\left(q_{t-1} S_{t}+b_{t}\right)-\frac{1}{N} L_{t}$. 
The total benefit from undercutting in period $t$ is the following: ${ }^{(26)}$

$$
\Pi_{t}^{U}=\frac{1}{N}\left[\frac{q_{t-1} S_{t}+b_{t}}{\theta w\left(M_{t}\right)}-L_{t}\right]\left(r_{t}^{L}-r_{t}^{L, c}\right)
$$

where $r_{t}^{L, c}$ is the competitive loan rate, and is equal to the marginal cost of loans:

$$
r_{t}^{L, c}=c_{L}+\frac{r_{t}^{D}+c_{D}}{1-\alpha}+\delta\left(M_{t}\right)
$$

If a bank deviates and cuts the loan rate, the other banks switch to a punishment strategy and set the loan rate equal to the competitive level indefinitely. In this case, for each period $j=t+1, t+2, \ldots \infty$, the deviating bank (and all the others) would earn zero profit. Therefore, the penalty imposed on the bank is equal to $\frac{1}{N} E_{t}\left[m_{t, 1} v\left(q_{t} s_{t+1}+b_{t+1}, x_{t+1}\right)\right]$. A bank optimally deviates from the co-operative equilibrium only if

$$
\Pi_{t}^{U}-\Pi_{t}>\frac{1}{N} E_{t}\left[m_{t, 1} v\left(q_{t} s_{t+1}+b_{t+1}, x_{t+1}\right)\right]
$$

where $\Pi_{t}$ is the profit under co-operative behaviour. The right-hand side of (A-44) is independent of loans whereas the left-hand side can be rewritten as:

$$
\left[\frac{q_{t-1} S_{t}+b_{t}}{\theta w\left(M_{t}\right)}-L_{t}\right] \frac{L_{t}}{l_{1}}-\frac{L_{t}^{2}}{l_{1}}
$$

The maximum gain in profit can be found by taking the derivative of (A-45) with respect to loans. I obtain the following:

$$
\arg \max \left(\Pi_{t}^{U}-\Pi_{t}\right)=\frac{1}{4} \frac{q_{t-1} S_{t}+b_{t}}{\theta w\left(M_{t}\right)}=\frac{1}{4} L_{t}^{*}
$$

(26) We are not considering the components of the profits, as given by equation (5), that do not depend on loans $L_{t}$. In fact, those terms cancel out when writing the condition for the existence of a co-operative equilibrium. 
and, at this level of loans, the profit gain is equal to

$$
\Pi_{t}^{U}-\Pi_{t}=\frac{1}{8 l_{1}}\left(L_{t}^{*}\right)^{2}
$$

Therefore, if (A-44) does not hold at a level of loans equal to $\frac{1}{4} L_{t}^{*}$, then a bank will never deviate from the co-operative strategy. However, if condition (A-44) is verified at $L_{t}=\frac{1}{4} L_{t}^{*}$, then there exists a neighbourhood around this quantity of loans such that a bank may deviate from the co-operative strategy and undercut the loan rate.

In conclusion, in the banking industry the capital constraint limits banks' ability to satisfy a larger share of loan demand at a lower loan rate. And it is precisely when demand is higher that the capital constraint is more likely to bind, ie during booms. Thus, capital requirements yield greater incentives for collusive behaviour. 


\section{References}

Basel Committee on Banking Supervision (2000), 'Range of practice in banks' internal ratings systems', Discussion Paper.

Basel Committee on Banking Supervision (2003), 'The new Basel Capital Accord', Consultative Document (CP3).

Basel Committee on Banking Supervision (2004), 'International convergence of capital measurement and capital standards: a revised approach', Basel Committee Publication no. 107.

Bernanke, B S and Lown, C S (1991), 'The credit crunch', Brookings Papers on Economic Activity, No. 2, pages 205-39.

Bliss, R and Kaufman, G (2002), 'Bank procyclicality, credit crunches, and asymmetric monetary policy effects: a unifying model', Federal Reserve Bank of Chicago WP 2002-18.

Borio, C, Furfine, C and Lowe, P (2001), 'Procyclicality of the financial system and financial stability: issues and policy options', BIS paper, www.bis.org/pub1/bispap01a.pdf.

Catarineu-Rabell, E, Jackson, P and Tsomocos, D P (2003), 'Procyclicality and the new Basel Accord - banks' choice of loan rating system', Bank of England Working Paper no. 181.

Chami, R and Cosimano, $\mathbf{T}$ F (2001), 'Monetary policy with a touch of Basel', IMF WP/01/151.

Chen, N-K (2001), 'Bank net worth, asset prices and economic activity', Journal of Monetary Economics, Vol. 48, pages 415-36.

Gordy, M B and Howells, B (2004), 'Procyclicality in Basel II: can we treat the disease without killing the patient?', Board of Governors of the Federal Reserve System, May Draft.

Hancock, D, Laing, A J and Wilcox, J A (1995), 'Bank capital shocks: dynamic effects on 
securities, loans, and capital', Journal of Banking and Finance, Vol. 19 (2), pages 661-77.

Haubrich, J G and Wachtel, P (1993), 'Capital requirements and shifts in commercial bank portfolios', Federal Reserve Bank of Cleveland Economic Review, Vol. 29 (Quarter 3), pages 2-15.

Jackson, P, Furfine, C, Groeneveld, H, Hancock, D, Jones, D, Perraudin, W, Radecki, L and Yoneyama, M (1999), 'Capital requirements and bank behavior: the impact of the Basel Accord', Basel Committee on Banking, www.bis.org/publ/bcbs_wp01.pdf.

Kashyap, A and Stein, J C (2004), 'Cyclical implications of the Basel II capital standards', Economic Perspectives, Federal Reserve Bank of Chicago, Issue Q1, pages 18-31.

Nickell, P, Perraudin, $W$ and Varotto, $S$ (2000), 'Ratings versus equity-based credit risk modelling: an empirical analysis', Bank of England Working Paper no. 132.

Thakor, A V (1996), 'Capital requirements, monetary policy, and bank lending: theory and empirical evidence', Journal of Finance, Vol. 51 (1), pages 279-324.

Tsomocos, D (2003), 'Equilibrium analysis, banking, contagion and financial fragility', Bank of England Working Paper no. 175.

Van den Heuvel, S (2001), 'The bank capital channel of monetary policy', mimeo, University of Pennsylvania.

Van den Heuvel, S (2002), 'Does bank capital matter for monetary transmission?', FRBNY Economic Policy Review, Vol. 8 (1), pages 259-65.

Wagster, J (1999), 'The Basel Accord of 1988 and the international credit crunch of 1989-1992', Journal of Financial Services Research, Vol. 15, pages 123-93. 